\title{
Quantifying Alfalfa Yield Losses Caused by Foliar Diseases in Iowa, Ohio, Wisconsin, and Vermont
}

F. W. Nutter, Jr., and J. Guan, Department of Plant Pathology, Iowa State University, Ames 50011; A. R. Gotlieb, Department of Plant and Soil, University of Vermont, Burlington 05405; L. H. Rhodes, Department of Plant Pathology, The Ohio State University, Columbus 43210; C. R. Grau, Department of Plant Pathology, University of Wisconsin, Madison 53706; and R. M. Sulc, Department of Horticulture and Crop Science, The Ohio State University

\begin{abstract}
Nutter, F. W., Jr., Guan, J., Gotlieb, A. R., Rhodes, L. H., Grau, C. R., and Sulc, R. M. 2002. Quantifying alfalfa yield losses caused by foliar diseases in Iowa, Ohio, Wisconsin, and Vermont. Plant Dis. 86:269-277.

Although foliar diseases of alfalfa occur throughout the United States wherever alfalfa is grown, little work has been done to quantify yield losses caused by foliar pathogens since the late 1980s. To quantify the yield losses caused by foliar diseases of alfalfa, field experiments were performed in Iowa, Ohio, Vermont, and Wisconsin from 1995 to 1998. Different fungicides and fungicide application frequencies were used to obtain different levels of foliar disease in alfalfa. Visual disease and remote sensing assessments were performed weekly to determine the relationships between disease assessments and alfalfa yield. Visual disease assessments of percentage of defoliation, disease incidence, and disease severity were performed weekly, approximately five to six times during each alfalfa growth cycle. Remote sensing assessments also were obtained weekly by measuring the percentage of sunlight reflected from alfalfa canopies using handheld, multispectral radiometers. Yield loss estimates were calculated as the yield difference between the fungicide treatment with the highest yield and the nonfungicide control, divided by the yield obtained from the highest yielding fungicide treatment $\times 100$. Over the 4-year period, significant alfalfa yield losses $(P \leq 0.05)$ occurred on 22 of the 48 harvest dates for the four states. The average significant yield loss for the 22 harvests was $19.3 \%$. Both visual and percentage of reflectance assessments were used as independent variables in linear regression models to quantify the relationships between assessments and alfalfa yield. From 1995 to 1998, visual disease assessments were performed for a total of 209 dates and remote sensing assessments were performed on 198 dates from the four states. Yield models were developed for each of these assessment dates. There were $26 / 209,26 / 209$, and 17/209 significant yield models based on percentage of defoliation, disease incidence, and disease severity, respectively. Most of the significant models were for disease assessments performed on or within 1 or 2 weeks of the date of alfalfa harvest. When the significant models were averaged, percentage of defoliation, disease incidence, and disease severity explained 51,55 , and $52 \%$ of the variation in alfalfa yield, respectively. There were a total of 68/198 significant alfalfa yield models based on remote sensing assessments, and the significant models (averaged) explained $62 \%$ of the variation in alfalfa yield. Alfalfa foliar diseases continue to have a significant negative impact on alfalfa yields in the United States and remote sensing appears to offer a better means to quantify the impact of foliar diseases on alfalfa yield compared with visual assessment methods.
\end{abstract}

Additional keywords: crop loss modeling, disease assessment, remote sensing

Alfalfa (Medicago sativa L.) is the most important forage crop grown worldwide (16). Foliar diseases, such as spring black stem and leaf spot (Phoma medicaginis Malbr. \& Roum. in Roum. var. medicaginis

Corresponding author: F. W. Nutter, Jr.

E-mail: fwn@iastate.edu

Journal paper No. J-19443 of the Iowa Agriculture and Home Economics Experiment Station, Ames, Iowa. Project No. 3394 and supported, in part, by Hatch and State of Iowa funds and a grant from the North Central Pesticide Impact Assessment Program.

Accepted for publication 23 October 2001.

Publication no. D-2002-0102-03R

(C) 2002 The American Phytopathological Society vere leaf loss (32). Foliar fungicides are recommended when disease is severe, but only cupric hydroxide is currently registered for use on alfalfa, and this fungicide provides only 30 to $60 \%$ disease control $(1,2,17,19,20,33)$.

Disease assessment is the process of quantitatively measuring disease intensity in a host population (5,25,27-29). Two general approaches can be employed to assess disease intensity in a plant population. The first involves a subjective visual disease assessment and the second involves an objective method of measuring reflected sunlight (22,24). Traditionally, visual disease assessment has been the approach most often employed by plant pathologists. This method relies upon subjective evaluation of disease intensity (such as disease incidence, disease severity, and percentage of defoliation) in a host population. Remote sensing has not been employed to assess the impact of foliar diseases on the health and productivity of alfalfa.

Remote sensing is an alternative method to assess disease. Remote sensing is defined as the acquisition of measurements from a sampling unit (alfalfa canopy) without physical contact between the measuring device and the sampling unit $(22,24,25)$. A major advantage of remote sensing is that plant canopies (sampling units) can be objectively and repeatedly analyzed, both nondestructively and noninvasively $(22,24)$. Plants may respond to disease stress in a number of ways, including leaf curling, stunting, wilting, defoliation, and chlorosis or necrosis of photosynthetic plant parts (25). Although many of these responses are difficult to quantify visually with acceptable levels of accuracy and speed, these same plant responses also affect the amount and quality of electromagnetic radiation reflected from plant canopies $(22,24,25)$. Handheld multispectral radiometers are one of the most common types of remote sensing instruments being used in plant pathology to assess the amount of disease injury in crops $(22,24)$.

Foliar diseases result in visible symptoms that can reduce the percentage of sunlight reflected from alfalfa canopies (25); therefore, we hypothesized that foliar diseases assessed visually and by remote sensing would both have significant relationships with alfalfa yield. The objectives 
of this study were to (i) determine the frequency of yield losses in alfalfa caused by foliar diseases in Iowa, Ohio, Vermont, and Wisconsin; (ii) quantify the relationships between visual disease and remote sensing assessments with alfalfa yield; and (iii) compare visual and remote sensing assessment methods to predict alfalfa yield reductions.

\section{MATERIALS AND METHODS}

Alfalfa plots were established in 1995 and 1996 using cv. ICI 630 in Iowa, Ohio, and Vermont, and cv. Persist in Wisconsin. These two alfalfa cultivars are highly resistant to bacterial wilt, Fusarium wilt, and Phytophthora root rot, and both are resistant to Verticillium wilt (6). Persist is moderately resistant to Aphanomyces root rot and anthracnose (Colletotrichum trifolii Bain \& Essary), whereas ICI 630 is resistant to both of these diseases. Although both cultivars are resistant to most races of C. trifolii, these cultivars are not reported to be resistant to any other foliar diseases of alfalfa (6).

Foliar disease epidemics were allowed to develop naturally in this study, except that four fungicides that varied in efficacy

Table 1. Fungicide treatments applied on alfalfa to generate different levels of disease for experiments conducted in Iowa, Ohio, Vermont, and Wisconsin between 1995 and 1998

\begin{tabular}{lcc}
\hline Fungicide & $\begin{array}{c}\text { Application } \\
\text { frequency }\end{array}$ & $\begin{array}{c}\text { Active } \\
\text { ingredient/ha }\end{array}$ \\
\hline Chlorothalonil & Once & 2.04 liters \\
Chlorothalonil & Twice & 2.04 liters \\
Cupric hydroxide & Once & $1.97 \mathrm{~kg}$ \\
Cupric hydroxide & Twice & $1.97 \mathrm{~kg}$ \\
Mancozeb & Once & $1.97 \mathrm{~kg}$ \\
Mancozeb & Twice & $1.97 \mathrm{~kg}$ \\
Propiconazole & Once & 0.25 liters \\
Propiconazole & Twice & 0.25 liters \\
CGA-245704 & Twice & $0.035 \mathrm{~kg}$ \\
Nonfungicide & & \\
control & None & $\ldots$
\end{tabular}

${ }^{a}$ Biological control treatment that was applied only in Iowa. (mancozeb, propiconazole, cupric hydroxide, and chlorothalonil) were used to differentially control foliar diseases of alfalfa $(1,2,11,13,17,19,20,31,33)$. To obtain a wider range of foliar disease levels, different application frequencies (once or twice per growth cycle) also were employed (Table 1). Of the four fungicides used in this study, only cupric hydroxide is currently registered for use on alfalfa and this fungicide is reported to be the least effective (of the four) in controlling foliar pathogens of alfalfa $(1,2,13,17,19,20,33)$. An additional biological control treatment (CGA-245704; Novartis Inc., Greensboro, NC) was used in Iowa. At each location and for each growth cycle, the first fungicide was applied when alfalfa canopies were approximately $15 \mathrm{~cm}$ high. The second fungicide application was applied 10 to 14 days following the first application. Fungicides were applied in 718 liters of water (equivalent) per hectare using a $\mathrm{CO}_{2}{ }^{-}$ pressurized sprayer at $40 \mathrm{psi}(276 \mathrm{kPa})$. The experimental design was a randomized complete block with four replications. Each plot was $7.5 \mathrm{~m}$ long and $1.8 \mathrm{~m}$ wide, with $1.2-\mathrm{m}$ borders surrounding each plot. Alfalfa yields were determined by harvesting the center 0.91 - to $1.22-\mathrm{m}$ strip of each plot when alfalfa reached $10 \%$ bloom. Sickle bar mowers were used in Iowa and Wisconsin, whereas forage flail harvesters were used in Ohio and Vermont. Subsamples of forage were dried in airforced ovens at $60^{\circ} \mathrm{C}$ to determine dry matter content. Plot fresh weight then was converted to dry matter yield. There were two harvests in the seeding year and three harvests in the subsequent years, except in Ohio, where there were four harvests following the seeding year. Percentage of yield loss was calculated as the difference between the highest yield achieved using fungicide and the yield from the control treatment, divided by the highest yield achieved $\times 100$ (28). The percentage of yield loss $(\mathrm{kg} / \mathrm{ha})$ for each location, date, and harvest (growth cycle) among fungicide treatments were tested for significance
$(P \leq 0.05)$ compared with controls using analysis of variance and orthogonal contrasts (SAS Institute, Cary, NC).

Visual disease assessments were conducted approximately once a week during each growth cycle $(13,15)$. Sampling for visual disease assessments began when alfalfa canopies were $15 \mathrm{~cm}$ high (just prior to the application of fungicides). Ten alfalfa stems were arbitrarily sampled from each plot by cutting the stems at the soil line for each disease assessment date (1$3,13,31)$. Percentage of defoliation was determined by counting the number of primary leaves (the leaf that develops from each node on a stem) missing from each node, divided by the total number of nodes $\times 100$. Disease incidence was determined by counting the number of symptomatic primary leaves, divided by the total number of primary leaves assessed for each alfalfa stem. Disease severity was determined by estimating the percentage of area covered by lesions due to foliar pathogens for each primary leaf present on each stem.

The percentage of sunlight reflected from alfalfa canopies was measured at each location using a handheld, multispectral radiometer (CROPSCAN Inc., Rochester, $\mathrm{MN}$ ). Both the incident radiation and the radiation reflected from alfalfa canopies were recorded simultaneously in eight narrow $(50-\mathrm{nm})$ wavelength bands with midpoint values at 460, 510, 560, 610, 660, 710, 760, and $810 \mathrm{~nm}$. All assessments were obtained using a sensor height of $2 \mathrm{~m}$ above the ground (14). The area of alfalfa canopy measured for each remote sensing assessment was a 1-m diameter circle (equal to one-half the sensor height).

Single-point yield models were constructed using linear regression for each assessment date by regressing visual disease and remote sensing assessments (obtained each week) against alfalfa yield using SAS (SAS Institute; 9,26). The goodness-of-fit for models was determined by evaluating the $F$ test $(P \leq 0.05)$ for each model, as well as the coefficient of determination $\left(R^{2}\right)$, the standard error of

Table 2. Predominant foliar pathogens present during each alfalfa growth cycle in Iowa, Ohio, Vermont, and Wisconsin in 1995 to 1998

\begin{tabular}{|c|c|c|c|c|}
\hline \multirow[b]{2}{*}{ State } & \multicolumn{4}{|c|}{ Alfalfa growth cycle ${ }^{a}$} \\
\hline & First & Second & Third & Fourth \\
\hline Iowa & $\begin{array}{l}\text { Phoma medicaginis var. medicaginis, } \\
\text { Pseudopeziza medicaginis, } \\
\text { Xanthomonas campestris pv. alfalfae }\end{array}$ & $\begin{array}{l}\text { Pseudopeziza medicaginis, } \\
\text { Cercospora medicaginis }\end{array}$ & $\begin{array}{l}\text { Leptosphaerulina briosiana, } \\
\text { Phoma medicaginis var. } \\
\text { medicaginis }\end{array}$ & \\
\hline Ohio & $\begin{array}{l}\text { Phoma medicaginis var. medicaginis, } \\
\text { Leptosphaerulina briosiana }\end{array}$ & $\begin{array}{l}\text { Leptosphaerulina briosiana, } \\
\text { Phoma medicaginis var. } \\
\text { medicaginis }\end{array}$ & $\begin{array}{l}\text { Leptosphaerulina briosiana, } \\
\text { Phoma medicaginis var. } \\
\text { medicaginis }\end{array}$ & $\begin{array}{l}\text { Leptosphaerulina } \\
\text { briosiana, Phoma } \\
\text { medicaginis var. } \\
\text { medicaginis }\end{array}$ \\
\hline Vermont & Phoma medicaginis var. medicaginis & $\begin{array}{l}\text { Phoma medicaginis var. } \\
\text { medicaginis, Pseudopeziza } \\
\text { medicaginis, Leptosphaerulina } \\
\text { briosiana, Stemphylium spp. }\end{array}$ & $\begin{array}{l}\text { Phoma medicaginis var. } \\
\text { medicaginis, Pseudopeziza } \\
\text { medicaginis, Leptosphaerulina } \\
\text { briosiana, Stemphylium spp. }\end{array}$ & 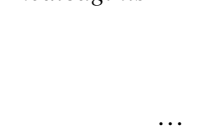 \\
\hline Wisconsin & $\begin{array}{l}\text { Phoma medicaginis var. medicaginis, } \\
\text { Pseudopeziza medicaginis, } \\
\text { Peronospora trifoliorum }\end{array}$ & $\begin{array}{l}\text { Pseudopeziza medicaginis, } \\
\text { Cercospora medicaginis, } \\
\text { Leptosphaerulina briosiana }\end{array}$ & $\begin{array}{l}\text { Phoma medicaginis var. } \\
\text { medicaginis, } \\
\text { Pseudopeziza medicaginis }\end{array}$ & $\ldots$ \\
\hline
\end{tabular}

a There were typically three growth cycles for all states except Ohio, in which there were four growth cycles per season. 
the estimate for $y$ (SEEy), the coefficient of variation $(\mathrm{CV})$, and a visual inspection of the residual plots (26). The $R^{2}$ indicates the proportion of the variation in alfalfa yield (Y) that is explained by an independent variable (visual or remote sensing assessments). The higher the $R^{2}$, the more variation in alfalfa yield that is explained by the independent variable. The SEEy is the square root of the unexplained variation of alfalfa yield, and it provides a measure of the error for predicted alfalfa yield. The lower the SEEy value, the more precise the model is to predict alfalfa yield. The CV, defined as the square root of mean square error (SEEy), divided by grand mean of $Y$ (alfalfa yield), was also used to test the precision of models. The higher the $\mathrm{CV}$ value, the lower the precision of the model (method) to predict yield (27).

\section{RESULTS}

Predominant foliar pathogens in the four states. The predominant foliar pathogens present during each growth cycle for each state are shown in Table 2. The predominant foliar pathogens among the four states were similar, except that Xanthomonas campestris pv. alfalfae (Riker et al.) Dye occurred in Iowa, Stemphylium spp. occurred in Vermont, and Peronospora trifoliorum de Bary occurred in Wisconsin.

Fungicide efficacy. Chlorothalonil applied once or twice per alfalfa growth cycle provided the best disease control (based on assessments of percentage of defoliation) for 22 of the 48 alfalfa growth cycles, whereas mancozeb applied once or twice provided the best disease control for 11 out of the 48 total growth cycles (Table 3). Propiconazole (applied once or twice) provided the best control for 9 of the 48 alfalfa growth cycles, whereas cupric hydroxide (applied once or twice) provided the best control for 6 alfalfa growth cycles (Table 3). Overall, a single application of any fungicide provided the best control for 15 of the 48 growth cycles, whereas two applications per growth cycle provided the best control for 33 of the 48 alfalfa growth cycles.

Yield loss frequencies. Alfalfa foliar diseases caused significant $(P \leq 0.05)$ yield losses in all four states from 1995 to 1998 (Table 4). Alfalfa foliar diseases caused significant yield losses for 22 out of 48 alfalfa harvests (growth cycles) that were conducted over the four states and 4 years. For the two locations (Ames and Nashua) in Iowa, yield losses ranged from 7.9 to $33.9 \%$, with an average of $16.5 \%$. Of the 16 harvests conducted at Iowa, 10 had significant yield losses when compared with the control plots. For Ohio, yield losses ranged from 3.0 to $23.0 \%$, with an average of $9.6 \%$, and 3 out of the 10 harvests had significant yield losses. For Vermont, yield losses ranged from 0.4 to $23.7 \%$, with an average of $15.0 \%$, and 8 out of the 14 harvests had significant yield losses. For Wisconsin, 1 out of the 8 harvests had a significant yield loss (14.7\%).

Although 26 of the 48 alfalfa harvests did not experience statistically significant yield losses, reductions in yield did occur in all 48 growth cycles. Among the 48 harvests in the four states from 1995 to 1998 , 5 harvests had yield losses less than 5\%, 17 harvests had yield losses between 5 and $10 \%, 8$ harvests had yield losses between 10 and 15\%, 7 harvests had yield losses between 15 and 20\%, 9 harvests had yield losses between 20 to $25 \%$, and 2 harvests had yield losses exceeding $25 \%$ (Fig. 1). No yield losses less than $5 \%$ occurred in Iowa during the period from 1995 to 1998 and all yield losses in Wisconsin were less than $15 \%$.

Table 3. Number of alfalfa growth cycles in which a specific fungicide treatment provided the best control of alfalfa foliar pathogens in Iowa, Ohio, Vermont, and Wisconsin in 1995 to $1998^{\text {a }}$

\begin{tabular}{lccccc}
\hline & \multicolumn{3}{c}{ State } & \\
\cline { 2 - 5 } Treatment $^{\mathbf{b}}$ & Iowa & Ohio & Vermont & Wisconsin & Total \\
\hline Chlorothalonil (1) $_{\text {Chlorothalonil (2) }}$ & 2 & 1 & 1 & 0 & 4 \\
Cupric Hydroxide (1) & 9 & 3 & 5 & 1 & 18 \\
Cupric Hydroxide (2) & 1 & 1 & 1 & 1 & 3 \\
Mancozeb (1) & 1 & 0 & 2 & 0 & 3 \\
Mancozeb (2) & 1 & 3 & 2 & 0 & 4 \\
Propiconazole (1) & 2 & 1 & 0 & 3 & 7 \\
Propiconazole (2) & 0 & 0 & 3 & 1 & 4 \\
CGA-245704 (2) $^{\mathbf{c}}$ & 0 & $\ldots$ & $\ldots$ & $\ldots$ & 5 \\
Nonfungicide control & 0 & 0 & 0 & 0 & 0 \\
Total cycles $^{\mathrm{d}}$ & 16 & 10 & 14 & 8 & 48 \\
\hline
\end{tabular}

${ }^{\text {a }}$ Best control is based upon assessments for percentage of defoliation.

${ }^{\mathrm{b}}$ The number in parentheses following the treatment indicates the number of applications per alfalfa growth cycle.

c This biological control treatment was used only in Iowa.

${ }^{d}$ Total number of alfalfa growth cycles for which fungicide treatments were evaluated in each state in 1995 to 1998.

Table 4. Alfalfa yield loss (\%) caused by foliar diseases in Iowa, Ohio, Vermont, and Wisconsin from 1995 to $1998^{\text {a }}$

\begin{tabular}{lccccc}
\hline & & \multicolumn{5}{c}{ Harvest $^{\mathbf{b}}$} \\
\cline { 3 - 6 } State, location & Year & $\mathbf{1}$ & $\mathbf{2}$ & $\mathbf{3}$ & $\mathbf{4}$ \\
\hline Iowa & & & & & \\
Ames & 1995 & $28.3^{*}$ & $33.9^{*}$ & $\ldots$ & $\ldots$ \\
& 1996 & $19.5^{*}$ & 8.8 & $11.7^{*}$ & $\ldots$ \\
Nashua & 1997 & $21.9^{*}$ & 16.6 & $10.2^{*}$ & $\ldots$ \\
& 1996 & 8.6 & $23.1^{*}$ & $\ldots$ & $\ldots$ \\
Ohio & 1997 & 7.9 & $8.3^{*}$ & $19.3^{*}$ & $\ldots$ \\
Columbus & 1998 & $15.7^{*}$ & $16.5^{*}$ & 13.9 & $\ldots$ \\
& & & & & $\ldots$ \\
Vermont & 1995 & 3.9 & $9.0^{*}$ & $\ldots$ & $\ldots$ \\
Swift & 1996 & $23.0^{*}$ & 5.5 & 3.0 & 13.3 \\
& 1997 & 9.3 & $14.3^{*}$ & 9.2 & 5.6 \\
Spear & 1995 & 17.2 & $23.7^{*}$ & & $\ldots$ \\
Wisconsin & 1996 & $18.4^{*}$ & $12.8^{*}$ & $22.1^{*}$ & $\ldots$ \\
Arlington & 1997 & $22.9^{*}$ & $20.1^{*}$ & $23.4^{*}$ & $\ldots$ \\
& 1996 & 5.7 & $20.6^{*}$ & 4.2 & $\ldots$ \\
& 1997 & 9.5 & 0.4 & 8.6 & $\ldots$ \\
\hline
\end{tabular}

a Percentage of yield loss was calculated as the difference between the highest yield achieved using fungicide and the yield from the control treatment, divided by the highest yield achieved $\times 100$.

b Percentage of yield loss followed by $*$ is significantly different from the control at $P \leq 0.05$ level using analysis of variance and orthogonal contrasts. 
percentage of defoliation. The SEEy ranged from 0.11 to $0.34 \times 10^{3} \mathrm{~kg} / \mathrm{ha}$, which indicates the standard error using percentage of defoliation to predict alfalfa yield would be \pm 110 to $340 \mathrm{~kg} / \mathrm{ha}$. CV values for those models ranged from 2.75 to 12.23 .
Yield models based on disease incidence. There were 26 significant yield models based on disease incidence among the total 209 models (12.4\%) for the four states over the 4 years (Table 6). Again, most of the significant models were for dates when disease incidence was assessed

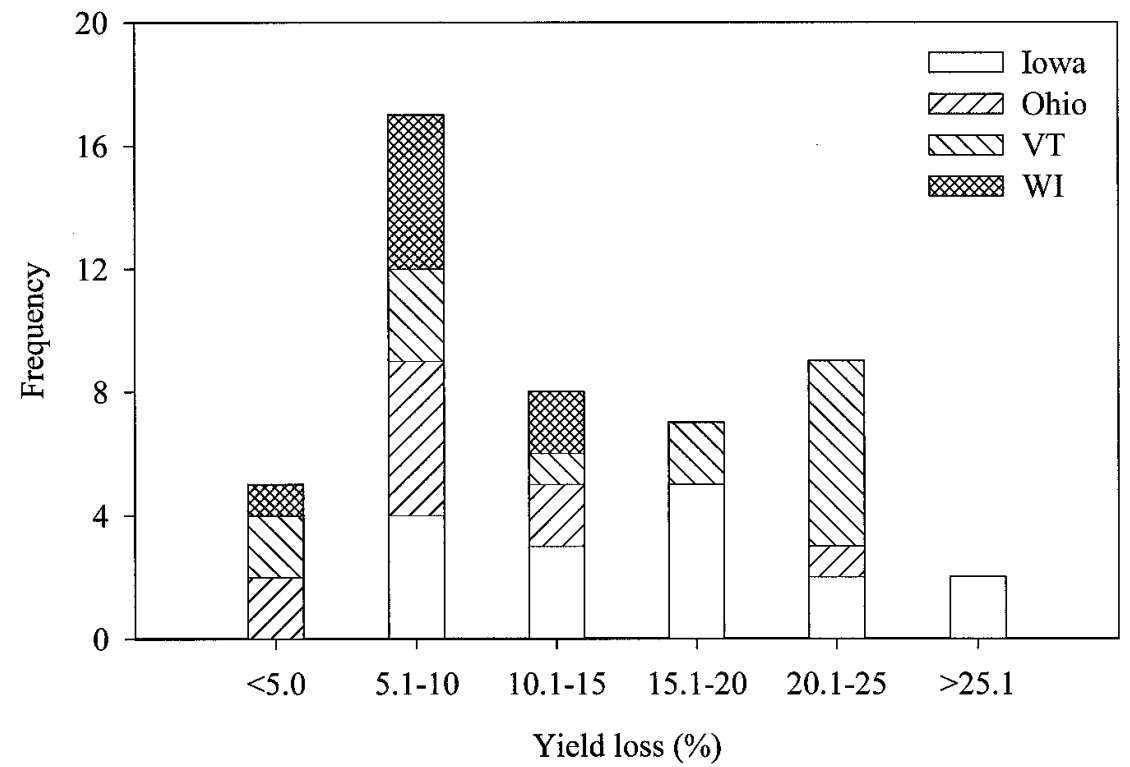

Fig. 1. Frequency of percentage of alfalfa yield lost due to foliar diseases for the 48 harvests in Iowa, Ohio, Vermont, and Wisconsin from 1995 to 1998. close to the time of harvest. The $R^{2}$ values for those 26 significant models ranged from 0.40 to 0.72 , which indicates that disease incidence explained up to $72 \%$ of the variation in alfalfa yield. The slopes for these significant models ranged from -0.0082 to $-0.1470 \times 10^{3} \mathrm{~kg} / \mathrm{ha}$, which indicates that alfalfa yield decreased 8.2 to $147 \mathrm{~kg} / \mathrm{ha}$ with each $1 \%$ increase in disease incidence. The SEEy ranged from 0.08 to $0.28 \times 10^{3} \mathrm{~kg} / \mathrm{ha}$, which indicates the standard error using disease incidence to predict alfalfa yield would be \pm 80 to 280 $\mathrm{kg} / \mathrm{ha}$. CV values for these significant models ranged from 1.64 to 12.08 .

Yield models based on disease severity. There were 17 significant yield models based on percentage of disease severity among the total 209 models $(8.1 \%)$ developed for the four states over the 4 years (Table 7). The $R^{2}$ values for these 17 significant models ranged from 0.39 to 0.76 , which indicates that disease severity explained up to $76 \%$ of the variation in alfalfa yield. The slopes for these significant models ranged from -0.0085 to -0.3000 $10^{3} \mathrm{~kg} / \mathrm{ha}$, which indicates that alfalfa yield decreased 8.5 to $300 \mathrm{~kg} / \mathrm{ha}$ with each $1 \%$ increase in disease severity. The SEEy ranged from 0.05 to $0.35 \times 10^{3} \mathrm{~kg} / \mathrm{ha}$, which indicates that the standard error using disease severity to predict alfalfa yield would be \pm 50 to $350 \mathrm{~kg} / \mathrm{ha}$. CV

Table 5. Coefficients of determination $\left(R^{2}\right)$, intercepts, slopes, standard errors of the estimate for $y$ (SEEy), and coefficients of variation (CV) for significant $(P \leq 0.05)$ alfalfa yield models based on percentage of defoliation for Iowa, Ohio, Vermont, and Wisconsin from 1995 to $1998^{\mathrm{a}}$

\begin{tabular}{|c|c|c|c|c|c|c|c|}
\hline State, location, year & Harvest & DOY $^{b}$ & $R^{2}$ & Intercept & Slope & SEEy & CV \\
\hline \multicolumn{8}{|l|}{ Iowa, Ames } \\
\hline \multirow[t]{3}{*}{1995} & 1 & 199 & 0.47 & 2.69 & -0.0797 & 0.18 & 11.86 \\
\hline & 1 & 209 & 0.44 & 2.26 & -0.0318 & 0.18 & 12.23 \\
\hline & 2 & 251 & 0.52 & 2.71 & -0.0252 & 0.15 & 9.55 \\
\hline \multirow[t]{4}{*}{1996} & 1 & 149 & 0.48 & 7.04 & -0.0379 & 0.23 & 4.15 \\
\hline & 1 & 155 & 0.48 & 7.34 & -0.0361 & 0.23 & 4.13 \\
\hline & 1 & 162 & 0.50 & 7.91 & -0.0472 & 0.22 & 4.06 \\
\hline & 3 & 247 & 0.50 & 7.55 & -0.0595 & 0.18 & 3.51 \\
\hline \multirow{4}{*}{1997} & 1 & 147 & 0.45 & 9.42 & -0.1360 & 0.34 & 6.03 \\
\hline & 1 & 153 & 0.49 & 10.99 & -0.1660 & 0.32 & 5.78 \\
\hline & 1 & 160 & 0.60 & 10.55 & -0.1410 & 0.29 & 5.11 \\
\hline & 3 & 230 & 0.48 & 5.06 & -0.0361 & 0.12 & 2.75 \\
\hline \multicolumn{8}{|l|}{ Iowa, Nashua } \\
\hline \multirow[t]{4}{*}{1996} & 1 & 178 & 0.55 & 3.72 & -0.1150 & 0.21 & 7.10 \\
\hline & 1 & 193 & 0.46 & 4.65 & -0.0836 & 0.23 & 7.73 \\
\hline & 2 & 227 & 0.52 & 3.31 & -0.0426 & 0.18 & 6.62 \\
\hline & 2 & 234 & 0.50 & 3.20 & -0.0246 & 0.18 & 6.76 \\
\hline \multirow[t]{2}{*}{1997} & 2 & 205 & 0.66 & 5.87 & -0.0467 & 0.13 & 3.11 \\
\hline & 3 & 243 & 0.59 & 5.31 & -0.0447 & 0.21 & 5.48 \\
\hline 1998 & 1 & 141 & 0.41 & 10.06 & -0.0943 & 0.23 & 3.60 \\
\hline \multicolumn{8}{|l|}{ Ohio, Columbus } \\
\hline 1995 & 1 & 186 & 0.50 & 4.66 & -0.0478 & 0.15 & 3.36 \\
\hline 1996 & 1 & 109 & 0.65 & 5.75 & -0.1030 & 0.24 & 5.20 \\
\hline 1996 & 1 & 144 & 0.44 & 8.65 & -0.1030 & 0.30 & 6.62 \\
\hline \multicolumn{8}{|l|}{ Vermont, Swift } \\
\hline 1996 & 3 & 232 & 0.64 & 4.31 & -0.0944 & 0.16 & 5.04 \\
\hline 1997 & 3 & 230 & 0.57 & 2.48 & -0.1100 & 0.11 & 7.23 \\
\hline \multicolumn{8}{|l|}{ Vermont, Spear } \\
\hline 1996 & 3 & 232 & 0.61 & 5.63 & -0.1230 & 0.27 & 6.70 \\
\hline 1997 & 2 & 189 & 0.43 & 1.57 & -0.0768 & 0.19 & 6.31 \\
\hline \multicolumn{8}{|l|}{ Wisconsin, Arlington } \\
\hline 1997 & 1 & 161 & 0.41 & 5.82 & -0.0432 & 0.13 & 3.38 \\
\hline
\end{tabular}

${ }^{a}$ Percentage of defoliation was determined by counting the number of primary leaves (the leaf that develops from each node on a stem) missing from each node, divided by the total number of nodes $\times 100$.

${ }^{\mathrm{b}} \mathrm{DOY}=$ day of year when disease defoliation assessment was conducted. 
values for these significant models ranged from 1.79 to 8.11 .

Yield models based on remote sensing assessments. Percentage of reflectance in the near-infrared wavelength bands (760 and $810 \mathrm{~nm}$ ) had stronger linear relationships with alfalfa yield (higher $R^{2}$ values) compared with the percentage of sunlight that was reflected between 460 and $710 \mathrm{~nm}$ (data not shown). Although models based on percentage of reflectance at 810 and $760 \mathrm{~nm}$ had a similar relationship with alfalfa yield, the 810-nm band had lower SEEy values, slightly higher $R^{2}$ values, and residuals that were more randomly distrib-

Table 6. Coefficients of determination $\left(R^{2}\right)$, intercepts, slopes, standard errors of the estimate for $y$ (SEEy), and coefficients of variation (CV) for significant $(P \leq 0.05)$ alfalfa yield models based on disease incidence for Iowa, Ohio, Vermont, and Wisconsin from 1995 to $1998^{\mathrm{a}}$

\begin{tabular}{|c|c|c|c|c|c|c|c|}
\hline State, location, year & Harvest & DOY $^{b}$ & $R^{2}$ & Intercept & Slope & SEEy & $\mathrm{CV}$ \\
\hline \multicolumn{8}{|l|}{ Iowa, Ames } \\
\hline 1995 & 1 & 185 & 0.46 & 7.56 & -0.0706 & 0.18 & 12.08 \\
\hline \multirow[t]{8}{*}{1996} & 1 & 121 & 0.62 & 7.55 & -0.0734 & 0.19 & 3.48 \\
\hline & & 127 & 0.55 & 7.50 & -0.0221 & 0.21 & 3.84 \\
\hline & 2 & 190 & 0.47 & 5.47 & -0.0123 & 0.10 & 2.25 \\
\hline & & 197 & 0.72 & 5.46 & -0.0140 & 0.08 & 1.64 \\
\hline & & 201 & 0.55 & 5.26 & -0.0083 & 0.10 & 2.06 \\
\hline & 3 & 233 & 0.59 & 7.16 & -0.0340 & 0.17 & 3.23 \\
\hline & & 240 & 0.40 & 7.00 & -0.0297 & 0.20 & 3.87 \\
\hline & & 247 & 0.43 & 9.83 & -0.0619 & 0.20 & 3.79 \\
\hline \multirow[t]{2}{*}{1997} & 2 & 181 & 0.64 & 18.46 & -0.1470 & 0.19 & 3.88 \\
\hline & 3 & 225 & 0.59 & 9.72 & -0.0614 & 0.11 & 2.46 \\
\hline \multicolumn{8}{|l|}{ Iowa, Nashua } \\
\hline \multirow[t]{3}{*}{1996} & 2 & 213 & 0.72 & 3.50 & -0.0266 & 0.14 & 5.08 \\
\hline & & 220 & 0.64 & 3.85 & -0.0207 & 0.15 & 5.65 \\
\hline & & 227 & 0.44 & 3.87 & -0.0210 & 0.19 & 7.10 \\
\hline \multirow[t]{3}{*}{1998} & 1 & 134 & 0.47 & 9.29 & -0.0365 & 0.22 & 3.45 \\
\hline & 2 & 189 & 0.71 & 15.53 & -0.1430 & 0.15 & 3.81 \\
\hline & 3 & 232 & 0.47 & 9.10 & -0.0688 & 0.18 & 5.07 \\
\hline \multicolumn{8}{|l|}{ Ohio, Columbus } \\
\hline \multirow[t]{5}{*}{1996} & 1 & 116 & 0.53 & 6.95 & -0.0393 & 0.28 & 6.08 \\
\hline & & 130 & 0.57 & 8.03 & -0.0477 & 0.26 & 5.79 \\
\hline & & 137 & 0.53 & 7.47 & -0.0426 & 0.28 & 6.08 \\
\hline & & 144 & 0.54 & 7.41 & -0.0371 & 0.27 & 6.03 \\
\hline & & 151 & 0.62 & 7.72 & -0.0401 & 0.25 & 5.49 \\
\hline 1997 & 4 & 245 & 0.45 & 3.40 & -0.0082 & 0.05 & 1.88 \\
\hline \multicolumn{8}{|l|}{ Vermont, Swift } \\
\hline 1996 & 3 & 247 & 0.50 & 6.76 & -0.0420 & 0.19 & 5.98 \\
\hline 1997 & 3 & 230 & 0.54 & 8.01 & -0.0710 & 0.12 & 7.48 \\
\hline \multicolumn{8}{|l|}{ Vermont, Spear } \\
\hline 1997 & 3 & 182 & 0.61 & 8.96 & -0.0686 & 0.15 & 5.22 \\
\hline
\end{tabular}

${ }^{a}$ Disease incidence was determined by counting the number of symptomatic primary leaves, divided by the total number of primary leaves assessed for each alfalfa stem $\times 100$.

${ }^{\mathrm{b}} \mathrm{DOY}=$ day of year when disease incidence assessment was conducted.

Table 7. Coefficients of determination $\left(R^{2}\right)$, intercepts, slopes, standard errors of the estimate for $y$ (SEEy), coefficients of variation (CV) for significant ( $P$ $\leq 0.05$ ) alfalfa yield models based on disease severity for Iowa, Ohio, Vermont, and Wisconsin from 1995 to $1998^{\mathrm{a}}$

\begin{tabular}{|c|c|c|c|c|c|c|c|}
\hline State, location, year & Harvest & DOY $^{b}$ & $R^{2}$ & Intercept & Slope & SEEy & $\mathrm{CV}$ \\
\hline \multicolumn{8}{|l|}{ Iowa, Ames } \\
\hline \multirow[t]{2}{*}{1995} & 1 & 199 & 0.76 & 3.81 & -0.1240 & 0.12 & 7.97 \\
\hline & 2 & 229 & 0.66 & 3.02 & -0.1900 & 0.13 & 8.11 \\
\hline \multirow[t]{3}{*}{1996} & 1 & 127 & 0.57 & 6.51 & -0.0842 & 0.21 & 3.76 \\
\hline & & 134 & 0.65 & 6.42 & -0.0832 & 0.19 & 3.41 \\
\hline & 2 & 201 & 0.50 & 5.19 & -0.1740 & 0.10 & 2.18 \\
\hline \multirow[t]{2}{*}{1997} & 1 & 132 & 0.47 & 7.69 & -0.2700 & 0.35 & 6.23 \\
\hline & 3 & 247 & 0.45 & 5.13 & -0.0648 & 0.13 & 2.98 \\
\hline \multicolumn{8}{|l|}{ Iowa, Nashua } \\
\hline \multirow[t]{2}{*}{1996} & 2 & 206 & 0.39 & 3.07 & -0.3000 & 0.20 & 7.43 \\
\hline & & 213 & 0.49 & 3.16 & -0.2930 & 0.18 & 6.76 \\
\hline 1997 & 2 & 198 & 0.50 & 5.35 & -0.1100 & 0.16 & 3.77 \\
\hline \multicolumn{8}{|l|}{ Ohio, Columbus } \\
\hline 1995 & 2 & 219 & 0.55 & 3.90 & -0.0928 & 0.12 & 3.90 \\
\hline \multirow[t]{2}{*}{1996} & 1 & 109 & 0.45 & 5.78 & -0.0836 & 0.30 & 6.57 \\
\hline & 1 & 116 & 0.45 & 6.26 & -0.0901 & 0.30 & 6.59 \\
\hline 1997 & 4 & 262 & 0.50 & 2.89 & -0.0085 & 0.05 & 1.79 \\
\hline \multicolumn{8}{|l|}{ Vermont, Swift } \\
\hline \multirow[t]{2}{*}{1995} & 2 & 210 & 0.59 & 4.92 & -0.0811 & 0.21 & 6.19 \\
\hline & & 229 & 0.42 & 4.19 & -0.0585 & 0.24 & 7.36 \\
\hline 1996 & 3 & 247 & 0.52 & 4.21 & -0.0806 & 0.18 & 5.83 \\
\hline Wisconsin, Arlington & No sigr & models & & & & & \\
\hline
\end{tabular}

${ }^{a}$ Disease severity was determined by estimating the percentage of area covered by lesions due to foliar pathogens for each primary leaf present on each stem.

${ }^{\mathrm{b}} \mathrm{DOY}=$ day of year when disease severity assessment was conducted. 
Table 8. Coefficients of determination $\left(R^{2}\right)$, intercepts, slopes, standard errors of the estimate for $y$ (SEEy), and coefficients of variation (CV) for significant $(P \leq 0.05)$ alfalfa yield models based on percentage of reflectance $(810 \mathrm{~nm})$ for Iowa, Ohio, Vermont, and Wisconsin from 1995 to $1998^{\mathrm{a}}$

\begin{tabular}{|c|c|c|c|c|c|c|c|}
\hline State, location, year & Harvest & DOY $^{\mathbf{b}}$ & $R^{2}$ & Intercept & Slope & SEEy & $\mathrm{CV}$ \\
\hline \multicolumn{8}{|l|}{ Iowa, Ames } \\
\hline \multirow[t]{3}{*}{1995} & 1 & 209 & 0.74 & -5.04 & 0.13 & 0.13 & 8.30 \\
\hline & 2 & 236 & 0.55 & -6.34 & 0.13 & 0.15 & 9.45 \\
\hline & & 251 & 0.72 & -1.87 & 0.067 & 0.12 & 7.73 \\
\hline \multirow{9}{*}{1996} & 1 & 127 & 0.51 & 0.44 & 0.11 & 0.22 & 4.01 \\
\hline & & 134 & 0.53 & 2.89 & 0.059 & 0.22 & 3.95 \\
\hline & & 141 & 0.55 & 1.97 & 0.065 & 0.21 & 3.87 \\
\hline & & 149 & 0.66 & -1.87 & 0.14 & 0.18 & 3.34 \\
\hline & & 155 & 0.77 & -1.42 & 0.14 & 0.15 & 2.78 \\
\hline & & 162 & 0.77 & -1.90 & 0.14 & 0.15 & 2.75 \\
\hline & 3 & 233 & 0.42 & -1.13 & 0.11 & 0.20 & 3.80 \\
\hline & & 240 & 0.73 & -2.24 & 0.13 & 0.13 & 2.59 \\
\hline & & 247 & 0.62 & -1.57 & 0.12 & 0.16 & 3.07 \\
\hline \multirow[t]{10}{*}{1997} & 1 & 132 & 0.44 & -7.85 & 0.35 & 0.32 & 5.78 \\
\hline & & 139 & 0.60 & -7.67 & 0.32 & 0.28 & 5.09 \\
\hline & & 147 & 0.53 & -12.11 & 0.36 & 0.31 & 5.55 \\
\hline & & 153 & 0.57 & -8.92 & 0.29 & 0.30 & 5.33 \\
\hline & & 160 & 0.69 & -8.27 & 0.29 & 0.25 & 4.50 \\
\hline & 2 & 195 & 0.80 & -2.60 & 0.15 & 0.14 & 2.93 \\
\hline & & 203 & 0.91 & -3.54 & 0.17 & 0.09 & 1.98 \\
\hline & 3 & 230 & 0.44 & -7.64 & 0.22 & 0.13 & 2.87 \\
\hline & & 237 & 0.69 & -4.42 & 0.16 & 0.10 & 2.12 \\
\hline & & 247 & 0.57 & -1.15 & 0.11 & 0.11 & 2.52 \\
\hline \multicolumn{8}{|l|}{ Iowa, Nashua } \\
\hline \multirow[t]{6}{*}{1996} & 1 & 178 & 0.49 & -3.29 & 0.14 & 0.22 & 7.52 \\
\hline & & 185 & 0.77 & -2.88 & 0.12 & 0.15 & 5.03 \\
\hline & & 193 & 0.75 & -3.20 & 0.13 & 0.15 & 5.27 \\
\hline & 2 & 220 & 0.65 & -5.95 & 0.17 & 0.15 & 5.71 \\
\hline & & 227 & 0.85 & -4.74 & 0.15 & 0.10 & 3.68 \\
\hline & & 234 & 0.78 & -0.62 & 0.07 & 0.12 & 4.47 \\
\hline \multirow[t]{5}{*}{1997} & 2 & 198 & 0.47 & -0.87 & 0.11 & 0.16 & 3.90 \\
\hline & & 205 & 0.76 & -0.31 & 0.10 & 0.11 & 2.65 \\
\hline & 3 & 226 & 0.54 & -14.38 & 0.39 & 0.23 & 5.82 \\
\hline & & 238 & 0.53 & -10.66 & 0.27 & 0.23 & 5.90 \\
\hline & & 243 & 0.44 & -4.95 & 0.17 & 0.24 & 6.19 \\
\hline \multirow[t]{6}{*}{1998} & 2 & 189 & 0.78 & -2.84 & 0.15 & 0.13 & 3.28 \\
\hline & & 197 & 0.90 & -2.01 & 0.13 & 0.10 & 2.25 \\
\hline & 3 & 219 & 0.48 & -3.12 & 0.17 & 0.18 & 5.03 \\
\hline & & 226 & 0.51 & -2.97 & 0.15 & 0.17 & 4.88 \\
\hline & & 240 & 0.44 & -0.52 & 0.09 & 0.18 & 5.18 \\
\hline & & 248 & 0.53 & -0.04 & 0.08 & 0.17 & 4.79 \\
\hline \multicolumn{8}{|l|}{ Ohio, Columbus } \\
\hline \multirow[t]{5}{*}{1995} & 1 & 182 & 0.46 & -2.36 & 0.13 & 0.15 & 3.49 \\
\hline & 2 & 220 & 0.87 & -4.42 & 0.16 & 0.07 & 2.07 \\
\hline & & 229 & 0.50 & -2.57 & 0.11 & 0.13 & 4.08 \\
\hline & & 233 & 0.45 & -3.76 & 0.12 & 0.14 & 4.28 \\
\hline & & 237 & 0.53 & -1.90 & 0.08 & 0.13 & 3.98 \\
\hline \multirow[t]{10}{*}{1996} & 1 & 130 & 0.45 & -8.21 & 0.23 & 0.30 & 6.54 \\
\hline & & 134 & 0.55 & -1.83 & 0.13 & 0.27 & 5.97 \\
\hline & & 151 & 0.53 & -3.12 & 0.15 & 0.27 & 6.04 \\
\hline & 4 & 232 & 0.65 & -6.07 & 0.18 & 0.09 & 8.89 \\
\hline & & 235 & 0.79 & -7.47 & 0.22 & 0.07 & 6.97 \\
\hline & & 239 & 0.85 & -5.62 & 0.15 & 0.06 & 5.86 \\
\hline & & 242 & 0.79 & -4.64 & 0.13 & 0.07 & 6.85 \\
\hline & & 247 & 0.80 & -4.99 & 0.14 & 0.07 & 6.73 \\
\hline & & 254 & 0.90 & -3.60 & 0.11 & 0.05 & 4.82 \\
\hline & & 262 & 0.68 & -3.31 & 0.11 & 0.09 & 8.47 \\
\hline \multirow[t]{4}{*}{1997} & 1 & 133 & 0.89 & -7.51 & 0.20 & 0.07 & 1.36 \\
\hline & & 139 & 0.60 & -9.00 & 0.22 & 0.12 & 2.57 \\
\hline & & 142 & 0.57 & -3.87 & 0.14 & 0.13 & 2.68 \\
\hline & & 170 & 0.55 & -4.81 & 0.19 & 0.19 & 3.83 \\
\hline
\end{tabular}

a Percentage of reflectance of sunlight reflected from plant canopies $(810 \mathrm{~nm})$ was measured using a hand-held CROPSCAN multispectral radiometer using a 2-m sensor height.

${ }^{\mathrm{b}}$ DOY $=$ day of year when reflectance data was collected.

uted; therefore, only percentage of reflectance at $810 \mathrm{~nm}$ was selected to develop alfalfa yield models.

There were 68 significant yield models based on percentage of reflectance at 810 $\mathrm{nm}$ among the total of 198 yield models $(34.3 \%)$ developed for the four states over the 4 years, and nearly all models based on assessment performed on the day of harvest or 1 week earlier were significant (Table 8). In Iowa, there were 39 significant models among a total of 91 yield models developed. The $R^{2}$ values for these 39 models ranged from 0.42 to 0.91 , which indicates that percentage of reflectance at $810 \mathrm{~nm}$ explained up to $91 \%$ of the variation in alfalfa yield. The intercepts ranged from -14.38 to $2.89 \times 10^{3} \mathrm{~kg} / \mathrm{ha}$. The slopes for the 39 significant models ranged from 0.059 to $0.39 \times 10^{3} \mathrm{~kg} / \mathrm{ha}$, which indicates that alfalfa yield increased 59 to 
Table 8. (continued from preceding page)

\begin{tabular}{|c|c|c|c|c|c|c|c|}
\hline State, location, year & Harvest & DOY $^{\mathbf{b}}$ & $R^{2}$ & Intercept & Slope & SEEy & $\mathrm{CV}$ \\
\hline \multicolumn{8}{|l|}{ Vermont, Swift } \\
\hline \multirow[t]{2}{*}{1995} & 1 & 179 & 0.61 & -2.26 & 0.09 & 0.09 & 13.00 \\
\hline & & 192 & 0.53 & -4.55 & 0.17 & 0.10 & 14.12 \\
\hline \multirow[t]{2}{*}{1996} & 1 & 182 & 0.59 & -3.37 & 0.18 & 0.14 & 3.92 \\
\hline & & 191 & 0.75 & -8.13 & 0.24 & 0.11 & 3.10 \\
\hline \multirow[t]{3}{*}{1997} & 1 & 147 & 0.53 & -7.10 & 0.25 & 0.17 & 4.54 \\
\hline & & 160 & 0.50 & -1.03 & 0.10 & 0.18 & 4.69 \\
\hline & 3 & 245 & 0.60 & -1.57 & 0.07 & 0.11 & 7.02 \\
\hline \multicolumn{8}{|l|}{ Vermont, Spear } \\
\hline \multirow[t]{3}{*}{1996} & 2 & 182 & 0.52 & -3.56 & 0.18 & 0.26 & 7.05 \\
\hline & & 191 & 0.48 & -4.03 & 0.15 & 0.27 & 3.39 \\
\hline & 3 & 232 & 0.45 & -4.19 & 0.15 & 0.32 & 7.92 \\
\hline Wisconsin, Arlington & No sig & t models & & & & & \\
\hline
\end{tabular}

Table 9. Total number of visual disease assessment dates and the total number of significant models based on visual disease assessments in Iowa, Ohio, Vermont, and Wisconsin from 1995 to 1998

\begin{tabular}{lcccc}
\hline & & \multicolumn{2}{c}{ No. of significant models based on } \\
\cline { 4 - 5 } State & No. dates $^{\mathbf{b}}$ & Defoliation $\mathbf{( \% )}^{\mathbf{c}}$ & Incidence $^{\mathbf{d}}$ & Severity $^{\mathbf{e}}$ \\
\hline Iowa & 88 & 18 & 17 & 10 \\
Ohio & 43 & 3 & 6 & 4 \\
Vermont & 55 & 4 & 3 & 3 \\
Wisconsin & 23 & 1 & 0 & 0
\end{tabular}

a Regression models were significant when $F$ statistics were $P \leq 0.05$.

b Total number of assessment dates; alfalfa plots were assessed weekly for each alfalfa growth cycle.

c Percentage of defoliation was determined by counting the number of primary leaves (the leaf that develops from each node on a stem) missing from each node, divided by the total number of nodes $\times 100$.

d Disease incidence was determined by counting the number of symptomatic primary leaves, divided by the total number of primary leaves assessed for each alfalfa stem $\times 100$

e Disease severity was determined by estimating the percentage of area covered by lesions due to foliar pathogens for each primary leaf present on each stem.

$390 \mathrm{~kg} / \mathrm{ha}$ with each $1 \%$ increase in percentage of reflectance at $810 \mathrm{~nm}$ for different assessment dates. SEEy ranged from 0.09 to $0.32 \times 10^{3} \mathrm{~kg} / \mathrm{ha}$, which indicates the standard error using percentage of reflectance to predict alfalfa yield was \pm 90 to $320 \mathrm{~kg} / \mathrm{ha}$. The $\mathrm{CV}$ for the 39 significant models ranged from 1.98 to 9.45 .

There were 19 significant models among the 53 models $(35.8 \%)$ developed in Ohio. The $R^{2}$ values for these 19 significant models ranged from 0.45 to 0.90 , which indicts that percentage of reflectance at $810 \mathrm{~nm}$ explained up to $90 \%$ of the variation in alfalfa yield. The intercepts ranged from -9.00 to $-1.83 \times 10^{3} \mathrm{~kg} / \mathrm{ha}$. The slopes ranged from 0.08 to $0.23 \times 10^{3}$ $\mathrm{kg} / \mathrm{ha}$, which indicates that alfalfa yield increased 80 to $230 \mathrm{~kg} / \mathrm{ha}$ with every $1 \%$ increase in percentage of reflectance. The SEEy ranged from 0.05 to $0.30 \times 10^{3}$ $\mathrm{kg} / \mathrm{ha}$. The CV ranged from 1.36 to 8.89 .

There were 10 significant models among 45 models $(22.2 \%)$ developed in Vermont. The $R^{2}$ values for the 10 significant models ranged from 0.45 to 0.75 , which indicates that percentage of reflectance at $810 \mathrm{~nm}$ explained up to $75 \%$ of the variation in alfalfa yield. The intercepts for these 10 significant models ranged from -8.13 to $-1.03 \times 10^{3} \mathrm{~kg} / \mathrm{ha}$. The slopes ranged from 0.07 to $0.25 \times 10^{3} \mathrm{~kg} / \mathrm{ha}$, which indicates that alfalfa yield increased 70 to $250 \mathrm{~kg} / \mathrm{ha}$ with each $1 \%$ increase in percentage of reflectance. The SEEy ranged from 0.09 to
$0.32 \times 10^{3} \mathrm{~kg} / \mathrm{ha}$, and the $\mathrm{CV}$ ranged from 3.10 to 14.12 . There were no significant models among the nine reflectance-based yield models developed in Wisconsin. There were more significant models based on remote sensing assessments than any of the three visual disease assessment methods.

Comparison of assessment methods. The total number of significant yield models based upon visual assessment methods in relation to the total number of visual disease assessments performed by each state is shown in Table 9. The total number of significant yield models based upon percentage of reflectance in relation to the total number of remote sensing assessments performed by each state is shown in Table 10. Based on these data, the remote sensing assessment method resulted in more significant regression models to predict alfalfa yields.

\section{DISCUSSION}

This research demonstrates that alfalfa foliar diseases had significant negative impacts on alfalfa yield for three of the four states involved in the study. The average yield loss caused by foliar diseases averaged over the 48 harvests, as determined by the difference between the highest yielding fungicide treatment and the nonfungicide-treated control, divided by the highest yielding fungicide treatment, was $13.2 \%$. Significant yield losses oc-
Table 10. Total number of remote sensing assessment dates and the total number of significant models based on percentage of reflectance at $810 \mathrm{~nm}$ in Iowa, Ohio, Vermont, and Wisconsin from 1995 to $1998^{a}$

\begin{tabular}{lcc}
\hline State & $\begin{array}{c}\text { Total number } \\
\text { of assessment } \\
\text { dates }^{\mathbf{b}}\end{array}$ & $\begin{array}{c}\text { Number of } \\
\text { significant }^{\text {models }} \mathbf{c}\end{array}$ \\
\hline Iowa & 91 & 39 \\
Ohio & 53 & 19 \\
Vermont & 45 & 10 \\
Wisconsin & 9 & 0 \\
\hline
\end{tabular}

${ }^{a}$ Percentage of reflectance of sunlight reflected from plant canopies $(810 \mathrm{~nm})$ was measured using a handheld CROPSCAN multispectral radiometer using a 2-m sensor height.

${ }^{b}$ Assessments were performed weekly for each alfalfa growth cycle.

${ }^{c}$ Regression models were significant when $F$ statistics were $P \leq 0.05$.

curred in 22 out of the 48 harvests and the yield loss for those 22 harvests averaged $19.3 \%$. These losses are a little lower than the results obtained by other researchers in other states $(3,4,16,30,32)$. For example, Campbell and Duthie reported that alfalfa yield losses caused by foliar diseases ranged from 5.3 to $37.2 \%$ per cutting in North Carolina (4). In Illinois, yield losses caused by foliar diseases were estimated to be as high as $52 \%$ per cutting, with an average loss of $15 \%$ each year, which was similar to our results (3). In Iowa, Norton reported that alfalfa yield was reduced $44 \%$ annually by foliar diseases (23). Wilcoxson et al. reported that alfalfa yield was reduced $30 \%$ annually by foliar diseases in Minnesota (35). In California, Gilchrist et al. reported annual yield losses of 20 to $25 \%$ caused by foliar diseases (8). Matheron and Matejka reported that alfalfa yield was increased 7.5 to $13.0 \%$ annually in Arizona when alfalfa was treated with the fungicide chlorothalonil to control foliar diseases $(19,20)$. Lengkeek reported that alfalfa yield was increased by $7.4 \%$ per cutting when foliar diseases were controlled using fungicide mancozeb in Kansas (17). In Wyoming, Gray et al. reported that spring black stem reduced alfalfa yield in the first cutting by approximately $10 \%$ (11). One reason that the estimated losses in the present study are slightly lower than 
the earlier reports from other studies is the improved resistance to anthracnose $(6,32)$. Moreover, other studies may have included losses from soilborne pathogens, but the present study dealt with quantifying only losses due to foliar pathogens.

The risk of foliar diseases causing significant yield loss for Iowa and Vermont was much higher than for Ohio and Wisconsin. Moreover, there were fewer significant yield models based on visual disease and remote sensing assessments in Wisconsin than in the other three states. In Wisconsin, few growth cycles had significant yield losses, and the range of yield response data within growth cycles was smaller than the range of yields for other states. Another reason that yield losses were lower in Wisconsin might be due to the fact that a different cultivar (Persist) was used in Wisconsin. It is possible that Persist may have been more resistant to foliar diseases than ICI 630, resulting in lower disease levels and a smaller range of visual disease, remote sensing assessments, and yield data among the different fungicide treatments. Cornell and Berger have reported that the $R^{2}$ is greatly affected by the range of the independent variables, and the smaller the range, the lower the coefficient of determination (7).

Although alfalfa breeding programs target specific diseases, a number of alfalfa foliar diseases continue to cause significant yield losses. This is because alfalfa cultivars that are resistant to a broad range of foliar diseases are not currently available (6). Attempts to utilize timely harvests prior to the occurrence of defoliation are often ineffective, as evidenced by the losses that occurred in our study and others $(3,4,13,23)$. Furthermore, no effective fungicides are currently registered for alfalfa foliar diseases $(17,19)$. The fungicide that was least effective in controlling foliar pathogens (cupric hydroxide) in this study is the only fungicide currently registered for use on alfalfa. Although the biological control treatment used in Iowa in this study did not provide effective disease control, alternative management tactics, including the use of effective biological controls, need to be investigated. Disease management tactics available to control alfalfa foliar diseases are presently limited.

Averaged over the 48 harvests, the yield loss for the four states over the 4-year period was $13.2 \%$. It is likely that this estimate is somewhat lower than the actual yield losses caused by alfalfa foliar pathogens because none of the fungicide treatments in this study provided $100 \%$ disease control. In this study, visual and remote sensing assessments explained a large proportion of the variation in yield using linear regression, and the unexplained variation in yield was likely due to other biotic pests (such as alfalfa weevil, leaf hoppers, and soilborne pathogens) as well as differences in environmental conditions that affected the yield potentials of experimental plots.

Assuming that the average yield of one hectare of alfalfa is 8.4 tons/year, and assuming there are approximately 9.7 million ha of alfalfa grown in the United States $(13,21)$, the average alfalfa yield loss is estimated to be approximately 10.76 million tons/year. Furthermore, according to the USDA weekly auction market report, the average alfalfa hay price in Iowa from 1995 to 1998 was $\$ 80 /$ ton. Assuming a similar average price throughout the United States, this makes the economic losses approximately equal to $\$ 860.8$ million/year in the United States.

This research confirmed our hypothesis that both visual and remote sensing assessments have significant relationships with yield; however, the remote sensing method predicted alfalfa yields with greater precision than any of the three visual disease assessment methods (disease incidence, disease severity, and percentage of defoliation) used in this study. The visual disease assessment methods used in this research only measure the impact of foliar diseases on alfalfa leaves located on the primary nodes of alfalfa stems. This method may not account for total impact that foliar diseases have on the growth and production of lateral branches and leaves. We observed that alfalfa foliar diseases cause premature defoliation and that, if primary leaves (located at the stem nodes) prematurely defoliate, very few lateral branches will develop from affected nodes. We suggest that sampling protocols in the future include the assessment of the presence or absence of lateral branches. Remote sensing assessments, however, provide information about the impact of foliar diseases on all leaves, including those that develop on lateral branches, because the higher the healthy (green) leaf area index, the higher the reflectance in the 810-nm wavelength band (13,24-26). In our study, remote sensing was superior to the visual disease assessment methods as a means to quantify the degree of the plant stress caused by alfalfa foliar pathogens and, thus, yield models based on remote sensing assessment could predict yield with greater precision. Remote sensing also had other advantages over visual disease assessment methods. Remote sensing is nondestructive and more objective than visual assessment methods. The time needed to conduct visual assessments took more than 15 times longer than remote sensing $(1 \mathrm{~h}$ compared to $15 \mathrm{~h}$ ). Remote sensing data were stored as electronic files; thus, potential errors associated with data entry also were avoided.

Overall, remote sensing provided a better means to assess the injury associated with foliar diseases than visual disease assessment methods. There are, however, some important factors that should be considered to obtain accurate remote sensing assessments. A potential disadvantage of the remote sensing method is that percentage of reflectance may be affected by factors other than disease, such as the amount of incident radiation, sun angle, sensor height, leaf wetness, fungicide residue, and wind $(12-15,18)$. These factors should be considered to ensure the accuracy and precision of remote sensing assessments.

\section{LITERATURE CITED}

1. Broscious, S. C. 1985. Evaluation of fungicides and application schedules for control of foliar diseases of alfalfa. Fungic. Nematic. Tests 40:116-117.

2. Broscious, S. C., and Kirby, H. W. 1985. Control of foliar diseases of alfalfa with fungicides. Fungic. Nematic. Tests 40:117-118.

3. Broscious, S. C., and Kirby, H. W. 1988. Economic evaluation of fungicides for control of alfalfa foliar diseases. Phytopathology 78:934-939.

4. Campbell, C. L., and Duthie, J. A. 1990. Impact of foliar diseases on yield and quality of alfalfa in North Carolina. Plant Dis. 74:241245.

5. Campbell, C. L., and Madden, L. V. 1990. Introduction to Plant Disease Epidemiology. John Wiley \& Sons, Inc., New York.

6. Certified Alfalfa Seed Council. 1997. Fall Dormancy and Pest Resistance Ratings for Alfalfa Varieties, 1996/1997 ed. Certified Alfalfa Seed Council, Davis, CA.

7. Cornell, J. A., and Berger, R. D. 1987. Factors that influence the value of the coefficient of determination in simple linear and nonlinear regression models. Phytopathology 77:63-70.

8. Gilchrist, D. G., Martensen, A. N., and Teuber, L. R. 1981. Effect of crown rot fungi on yield components and stand persistence of nondormant alfalfa in California. (Abstr.) Phytopathology 71:219.

9. Gomez, K. A, and Gomez, A. A., 1984 Statistical Procedures for Agricultural Research. Wiley, New York.

10. Gray, F. A. 1983. Assessment of foliage diseases of alfalfa in Wyoming. Plant Dis. 67:1156-1158.

11. Gray, F. A., Fernandez, J. A., and Horton, J. L. 1987. Efficacy of chlorothalonil for control of spring black stem and common leaf spot of alfalfa. Plant Dis. 71:752-755.

12. Gross, M. F., Hardisky, M. A., and Klemas, V. 1988. Effects of solar angle on reflectance from wetland vegetation. Remote Sens. Environ. 26:195-212.

13. Guan, J., 2000. Assessing disease stress and modeling yield losses in alfalfa. Ph.D. dissertation. Iowa State University, Ames.

14. Guan, J., and Nutter, F. W., Jr. 1998. Effect of incident radiation, sun angle, and sensor height on the percentage of sunlight reflected from alfalfa canopies affected by foliar diseases. (Abstr.) Phytopathology 88:S115.

15. Guan, J., and Nutter, F. W., Jr. 2001. Factors affecting the quality and quantity of sunlight reflected from alfalfa canopies. Plant Dis. 85:865-874.

16. Hanson, A. A., Barnes, D. K., and Hill, R. R., Jr. 1988. Alfalfa and Alfalfa Improvement. American Society of Agronomy, Crop Science Society of America, and Soil Science Society of America, Madison, WI.

17. Lengkeek, V. H. 1980. Field and cereal crop disease reports: alfalfa. Fungic. Nematic. Tests 36:83.

18. Lord, D., DesJardins, R. L., and Dube, P. A. 1985. Influence of wind on crop canopy reflectance measurements. Remote Sens. Environ. 18:113-123.

19. Matheron, M. E., and Matejka, J. C. 1987. Field crops reports: alfalfa. Fungic. Nematic. 
Tests 44:169.

20. Matheron, M. E., and Matejka, J. C. 1988. Cereal and forage reports: alfalfa. Fungic. Nematic. Tests 45:168.

21. National Agricultural Statistics Service, 1999. Crop Production. U. S. Dep. Agric. Washington, D.C.

22. Nilsson, H. E. 1995. Remote sensing and image analysis in plant pathology. Annu. Rev. Phytopathol. 15:489-527.

23. Norton, D. C. 1965. Xiphinema americanum population and alfalfa yields as affected by soil treatment, spraying and cutting. Phytopathology 55:615-619.

24. Nutter, F. W., Jr. 1990. Remote sensing and image analysis for crop loss assessment. Pages 93-105 in: Crop Loss Assessment in Rice. International Rice Research Institute, Los Banos, Philippines.

25. Nutter, F. W., Jr., and Gaunt, R. E. 1996. Recent developments in methods for assessing disease losses in forage/pasture crops. Pages 93-118 in: Pasture and Forage Crop Pathology. American Society of Agronomy, Crop Science Society of America, and Soil Science Society of America, Madison, WI.

26. Nutter, F. W., Jr., and Littrell, R. H. 1996. Relationships between defoliation, canopy reflectance and pod yield in the peanut-late leaf spot pathosystem. Crop Prot. 15:135-142.

27. Nutter, F. W., Jr., and Schultz, P. M. 1995. Improving the accuracy and precision of disease assessments: selection of methods and use of computer-aided training programs. Can. J. Plant Pathol. 17:174-184.

28. Nutter, F. W., Jr., Teng, P. S., and Royer, M. H. 1993. Terms and concepts for yield, crop loss, and disease thresholds. Plant Dis. 77:211-215.

29. Nutter, F. W., Jr., Teng, P. S., and Shokes, F. M. 1991. Disease assessment terms and concepts. Plant Dis. 75:1187-1188.
30. Rhodes, L. H., and Myers, D. K. 1986. Severity of spring black stem on alfalfa cultivars in Ohio. Plant Dis. 70:746-748.

31. Rizvi, S. S. A., and Nutter, F. W., Jr. 1993. Seasonal dynamics of alfalfa foliar pathogen in Iowa. Plant Dis. 77:1126-1135.

32. Stuteville, D. L., and Erwin, D. C. 1990. Compendium of Alfalfa Diseases. 2nd ed. American Phytopathology Society, St. Paul, $\mathrm{MN}$.

33. Vincelli, P. C., Collins, M., and Doney, J. 1992. Control of Sclerotina crown and stem rot of alfalfa. Fungic. Nematic. Tests 47:211

34. Von Chong, K., and Campbell, L.C., 1988 Seasonal occurrence of leaf spot pathogens of alfalfa in North Carolina. Plant Dis. 72:667672.

35. Wilcoxson, R. D., Bielenberg, O., and Bissonnette, H. L. 1973. Yield of alfalfa hay increased by control of foliar diseases. Plant Dis. Rep. 57:353-354. 